\title{
Mixed methodology for the identification of a first generation, transnational, minority elite
}

\author{
Hanna Edit, Kónya -Research Center for Educational \\ and Network Studies (RECENS), Corvinus University of \\ Budapest $^{1}$ \\ Eliza Hajnalka, Bodor-Eranus \\ MTA TK "Lendület" Research Center for Educational \\ and Network Studies (RECENS)
}

DOI: https://doi.org/10.5565/rev/periferia.623

\begin{abstract}
.
The heterogenous self-identifications of the group members, the multitude of interactions, the mix of personal and community interests and the parted opinion about the role of migrant members of the community create a social setting urging for a research methodology specifically developed for this fieldwork. Current article presents a mixed methodology using social network analysis, representative survey and qualitative interviews for the identification of the elite. Seen the methods individually, three very different definitions are provided, while confronting the results allows for a more accurate definition and identification of the elite.
\end{abstract}

Keywords: mixed methods, minority, transnational, elite.

Resumen. Los métodos mixtos en la identificación de una élite trasnacional de primera generación

La heterogeneidad de las auto-identificaciones de los miembros de un grupo, la cantidad de interacciones, la mezcla de intereses individuales y de comunidad y la opinión dividida sobre el rol del miembro migrante en una comunidad crea un contexto social para el cual es necesario desarrollar una metodología de investigación específica. En el presente artículo, se describe una metodología mixta usando análisis de redes sociales, una encuesta representativa, y entrevistas cualitativas para la identificación de la élite. Al analizar los métodos individualmente, tres definiciones diferentes emergen, las cuales proveen una definición y una identificación de dicha élite mucho más específica, una vez contrastadas con los resultados.

${ }^{1}$ Corresponding author: Hanna Edit Kónya, hanna.konya@uni-corvinus.hu 
Hanna Edit Kónya, Mixed methodology for the identification of a first generation, transnational, minority elite, perifèria 22(2), diciembre 2017

revistes.uab.cat/periferia

Palabras Clave: métodos mixtos, minoría, trasnacional, élite.

\section{Research context}

Moldova (eastern part of Romania) is still considered an underdeveloped region of Europe; underdeveloped in economic aspects, infrastructure and political culture and mentality (Arens and Bein, 2004). The Roman Catholic minority from Moldova is known as Csángó, and while most people of the area know who the term refers to, the actual size of the community is uncertain. During the communist period the Csángó community went through a strong assimilation process, that led to Romanian language being not only the official language, but also being the language of education and worship. The size of the community differs on the number of minimum items required for identification. If identification is based solely on religion - Roman Catholics among Orthodox -, according to Church statistics, the number of the community is around 250.000. If religion and language - some form of Hungarian - are both considered, the community counts around 62.000 members (Tánczos, 1997). While we rely on the national census - self declaration of Csángó identity - is also needed, the community counts less than 2,000 people.

Theories on Csángó origin are grouped in 4 categories (Pozsony, 2002:9-21). First theory sees the origin in Hungarians who settled outside of the Carpathians in the 9th century (Rubinyi, 1901, Gunda, 1988). The second approach sees Csángós as descendants of some nations with a Turkish language (Munkácsi, 1902, Iorga, 1993). Third theory, the most widely accepted by the scientific community, argues that Csángós are descendants of Hungarians, who went to Moldova from the Carpathian basin in the 13th-14th centuries, and a greater group in 1764, after the Massacre from Mádéfalva (Benda, 1989, Benko', 1989, Domokos, 1987, Rosetti, 1905, Lüko', 1936). The fourth - a highly debated - theory, proposed by Martinas, (1985), sustains that Csángós are descendants of Romanians assimilated in Transylvania. 
Hanna Edit Kónya, Mixed methodology for the identification of a first generation, transnational, minority elite, perifèria 22(2), diciembre 2017

revistes.uab.cat/periferia

With the regime change a new phenomena took great proportions that once again highly influenced the identity of several members of the community. Due to international migration with the goal of higher education or work, several young members of the community started to learn in Hungarian schools in Transylvania, initiating a process that is seen today as the emergence of a transnational elite, while even more enrolled in foreign guest working in Hungary, Spain, Italy and Israel (Sandu, 2005).

The substantive question of the research is the identification of the Csángó elite. While elite studies have a great heritage in social sciences, the innovative character of the proposed methodology stands in focusing on a developing elite, that is transnational and while geographically is not restricted to one region, it implements the feedback received from the community as well. The definition of the Csángó elite, the roles, positions and status of the members within the community, lays in understanding in a minority context the importance of ethnic and religious identity, as well as strength of transnational migration in structuring a traditional society.

The definition of elites can be very complex and often different characteristics of the elite are considered important and decisive. From the ruling class theory (ex. Marx (1846) 2004, Konrád and Szelényi, 1979, King and Szelényi, 2004, Pakulski and Waters, 1996), elite theories (ex. Higley and Gunther, 1991, Etzioni-Halévy, 1997, Marcus, 1983, Higley, Burton, and Field, 1990), the plural elite model (Dahl, 1961, Rose, 1967, etc.), the behaviorist identification (Lasswell, 1936), to the functionalist approach (Rustow, 1996: 696) most define the elite along the accumulation of different capitals.

Some authors argue that material capital and power as such is not the most important, but rather the emerging and critical form of the cultural/human capital is (Pakulski and Waters, 1996). While considering the importance of human and social capital contributes greatly to the understanding of the Csángó elite, is just as important to consider the social circle theory (Kadushin, 1968), as in this case as well, members are brought together by a common interest or goal rather than a formal membership and/or granted characteristics based on certain criteria or roles. The anthropological approach (Shore and Nugent, 2002) brings new insights to the 
Hanna Edit Kónya, Mixed methodology for the identification of a first generation, transnational, minority elite, perifèria 22(2), diciembre 2017

revistes.uab.cat/periferia

definition and identification of the Csángó elite, by focusing on how the members of the elite operate, how they relate to the community, and how they define culture. During fieldwork three problems present in the anthropological approach were considered:

a.) the problem faced by elites, to attune universalism and particularism (Cohen, 1981)

b.) recognition of the elite position by themselves or by the community, referring to Marcus's interpretation of the elite concept a "term of reference rather than a selfreference" (Marcus, 1983:9)

c.) the Janus-type existence of elites, who "both do 'modernize' their immediate environment, surrounding themselves with powerful symbols of distinction to mitigate the effects of their rural attachments, while at the same time bolstering these attachments primarily through recourse to a gendered division of symbolic labour - in order to maximize local trust and acceptability." (Harvey, 2002:84)

Nugent draws attention on the difficulties of Amazonian elite investigation that are valid in the identification of the Csángó elite as well, 1.) not having a generic Amazonian society, 2.) being a mosaic society, that is "socially amorphous and naturally rigid", 3.) there is no historical background for - pre-modern - elites that have continuity in current configurations and 4.) having elite members outside of Amazonia (Nugent, 2002). Studying the elite transformation in Nepal, Lotter (2004) defined as elites not only those who would be seen as such on international level as well, but those too, who outside of Nepal based on their living standards would be defined as middle class.

\section{Methodology and data}

Conducting fieldwork among elites is a constant negotiation and adjustment of researchers regarding their position in the field, and these changes aren't always intended, conscious and planned strategies, or individual choices (Fumanti, 2004). Through extensive fieldwork in Romania and Hungary, three data collections were 
Hanna Edit Kónya, Mixed methodology for the identification of a first generation, transnational, minority elite, perifèria 22(2), diciembre 2017

revistes.uab.cat/periferia

conducted: through interviews, social network analysis and representative survey (this latter one restricted to one locality).

As a first step, using snowball sampling - initiated with 4 subjects - a nomination of 20 Csángó elites was collected. Following the nominations until no new name appeared ( 57 nominations were made), those nominees were considered as elites who received at least 4 votes during the snowball sampling. They became the interview subjects, they are the elite defined by snowball sampling and the qualitative methodology. A total of 27 interviews were conducted with the members of the elite and couple of non-Csángós, leaders of the most important organizations working in the region on a daily basis for the preservation of the Csángó culture and heritage. To avoid influencing the elite definition of the interview subjects, they were informed only in keywords (Lee, 1993) about the focus of the research.

Relational data collects all collaborations in the Csángó matter. The Csángó matter is a joint name for all actions and initiatives aiming the preservation of the cultural heritage. It is promoted and supported by several NGOs, politicians, public and private individuals. The collaboration network was created by merging 44 Egonetworks of all interviewees, representatives of major associations dealing with the Csángó matter, and several teachers active in the extra-curricular Hungarian teaching, the most important action of the Csángó matter. Using social network indicators, network roles and positions were analyzed in order to determine who plays a key role in the Csángó matter, resulting as such in a different understanding and definition of the elite.

Representative data was collected in one locality of nearly 430 families, 1400 habitants. 182 questionnaires were filled out by the household head of nearly half $(42,3 \%)$ of the families. The identification of the Csángó elite resulting in yet another definition.

Confirmation or refutation of the elite group/composition drawn by the qualitative method (and the snowball sample) is confronted by the social network analysis and the survey. The snowball sampling is called to correct the potential preconceptions and definitions that I could have as an outsider and as a researcher. The goal of the 
Hanna Edit Kónya, Mixed methodology for the identification of a first generation, transnational, minority elite, perifèria 22(2), diciembre 2017

revistes.uab.cat/periferia

mixed methodology was to identify and present the elite as they see themselves and also how the community they represent through their actions recognizes them. The three methods jointly are able to identify and present not only an introspective but an external definition of the Csángó elite as well, meanwhile characterizing the members and the group(s) by their roles, status, position, respect, hierarchy, etc.

\section{Elite definitions}

Before presenting the findings of the different research methods the topic of the "Csángó matter" needs clarification, as in all methodological approaches the role played in the Csángó matter was present. Defined shortly is the preservation of the Csángó culture and the representation of the society. The Csángó matter involves several organizations, foundations, political parties and individuals; and is active in different cultural, social, health related, religious and educational events. Some of the main goals of the Csángó matter are: maintaining the cultural characteristics of the Csángó community, slowing the assimilation process, maintaining or reintroducing the usage of Hungarian language into the everyday life, creating the possibility of having religious masses in Hungarian language, publishing scientific works about the past and present of this minority, etc.

The specific research methods proved to put focus differently on the traditional categories of material, political and cultural elites. In the following we will present the different elite definitions received by each methodology and then we will synthesize what the mixed methods added to the original definitions and identifications.

\section{The Csángó elite according to the elite - The Interview results}

The snowball sample collected 57 names with more than 4 nominations as elites. 40 out of the 57 people is younger than 40 years old, and 38 are male. The identified elite, has members living in Moldova and in Hungary, and the majority 43 people - studied in Hungarian language as well, either by being at school between 1947-1959, when formal Hungarian teaching was official in Moldova, or they went to school to Transylvania or to Hungary after the 1989 political regime 
Hanna Edit Kónya, Mixed methodology for the identification of a first generation, transnational, minority elite, perifèria 22(2), diciembre 2017

revistes.uab.cat/periferia

change. Among the nominees there are several leaders of formal organizations involved, active in different aspects of the Csángó matter. There are 2 priests among the nominees, both living and working in Hungary, one of them being active in organizing Hungarian masses for Csángós in Moldova. Further 8 people of the nominees were named for their interest and activity in the scientific aspect of the culture of the minority, they regularly participate to conferences and publish journal articles and books about some aspect of the Csángó community. Only 6 were named for their activity in the political representation of the community. 23 of the named elites, are representing Csángós and the Csángó matter at an international level, they are present both in Hungarian and the Moldova context of Csángó context of Hungary and Moldova. Nearly half of the elites nominated by the snowball sample were interviewed. Interviews lasted on average around 2-3 hours. At the beginning of the interviews all subjects were asked if they think there is a "Csángó elite" and if yes how would they define it. For the majority of interviewees, the Csángó elite is in the process of development greatly as a result of the possibilities brought by the 1989 regime change.

The interviewees see the cultural elite as the largest, most active elite group, mostly formed by a highly educated young generation with a strong Hungarian/Csángó-Hungarian identity, due to their education in Transylvania and/or Hungary. The group is characterized with a strong sense of duty towards their communities, a goal to preserve their cultural heritage and to fight assimilation. The group is geographically spread, with members from Moldova and other parts of Romania, to Hungary. They consider themselves role-models and while they seek to present education as an alternative channel for vertical mobility - beside foreign guest-working, they see their social position in the community uncertain, especially if the higher education is not partnered with higher material well-being as well. If we consider the validation of elite positions, by the roles the members fulfill toward the community they represent, and weather this can be done from $1000 \mathrm{~km}$ away or one has to be locally present, leads to divided opinions. Some think that the young generation of Csángós with university degrees from Hungary should return to Moldova - although their integration into the 
Hanna Edit Kónya, Mixed methodology for the identification of a first generation, transnational, minority elite, perifèria 22(2), diciembre 2017

revistes.uab.cat/periferia

emissive society meets difficulties, - while others think that returning is not only not compulsory, but these young educated Csángós might actually serve their community better by remaining in Hungary where/from where they have a strong lobby power.

Another group of the elite also defined by the interview method, is a group of older Csángós who represent a fading traditional knowledge of folk dances, songs, musical instruments and traditional healing practices. This fading knowledge has high prestige and value in the eyes of the young members of the elite, who during their years in Transylvania and in Hungary learned the value of their folk culture and traditions. With formal, organizational background these members of the elite are playing an active role in (re)teaching these traditions and customs to the young generation and in representing the community in different folk events both home and abroad.

They interviewed elite, holds themselves responsible for shaping the future of the community, to maintain their cultural heritage, to fight assimilation and to strengthen the weakening Hungarian (self)identification. The character of the Csángó elite - as defined by the elite himself - can be understood by following Herzfeld's observation about the channel for elites for preserving their position and power by "monumentalizing the past" (Herzfeld, 2000:234).

Understanding the use of cultural elements of the past as capital and legitimation form, is central in the presentation of the major interests and conflicts of the Csángó elites defined by the snowball and interview method. The lack of identifying any members of the economci or political elite - even at local level - asks for further methodology for the more accurate definition and identifiction of the Csángó elite.

\section{The Csángó elites of the Csángó matter - Social network analysis}

Social network analysis was used to identify the central actors in the Csángó matter, a joint name for all actions and events that aim to serve the community. Dealing with a collective action spreading across 25 years and two countries, with regular and occasional members, both individuals and organizations conducting a 


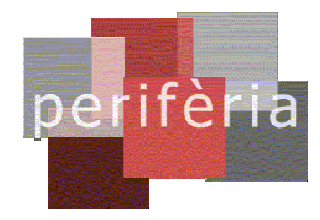

Hanna Edit Kónya, Mixed methodology for the identification of a first generation, transnational, minority elite, perifèria 22(2), diciembre 2017

\section{revistes.uab.cat/periferia}

whole network analysis in a traditional way was nearly impossible as no list of all participants is available, nor is it possible to collect information regarding all ties.

In order to build up the whole network, ego networks regarding the collaboration within the Csángó matter were collected from 44 people, all active on daily basis in several projects. Merging the ego-networks along all ties named at least once, resulted in a cooperation network of 482 actors with 1777 relations, in which central actors and key roles and positions were identified. Two demographic attributes were included in the analysis, ethnic identification and place of residence of all actors according to the interviewed egos.

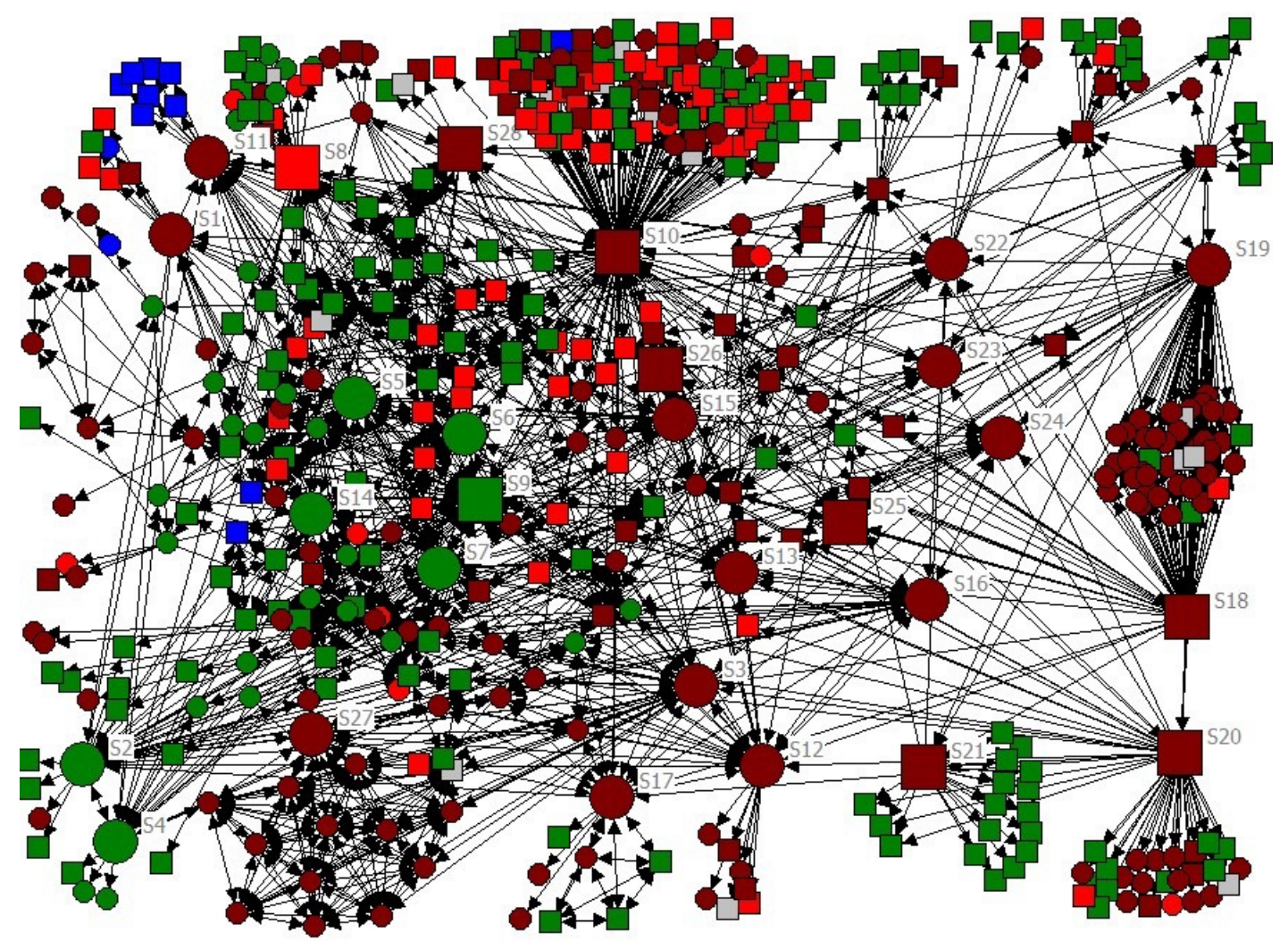

Legend: •Moldova, • Romania but Moldova, • Hungary, • Other, •No data; oCsángó, $\square$ Not Csángó

Figure 1. Collaboration network in the Csángó matter by ethnicity and place of residence

The Csángó matter has equal representation - close to $40 \%$ of the active members 
Hanna Edit Kónya, Mixed methodology for the identification of a first generation, transnational, minority elite, perifèria 22(2), diciembre 2017

\section{revistes.uab.cat/periferia}

- in Moldova and in Hungary. The collaboration is a densely connected network, that is not divided along geographic regions, as it has many relations connecting Moldova, other parts of Romania and Hungary, yet it is divided by ethnicity. While the proportion is almost the same, the following table shows that in Moldova the majority of participants are Csángó, while in Hungary the majority are not Csángós, suggesting that in both regions locals are being involved. The non Csángó actors highly active in Moldova, are mostly the teachers of the extracurricular Hungarian teaching.

Table 1. Distribution of actors of the collaboration network by residence and ethnicity.

\begin{tabular}{|l|r|r|r|r|r|r|}
\hline & Moldova & Romania & \multicolumn{1}{l|}{ Hungary } & \multicolumn{1}{l|}{ Other } & No data & \multicolumn{2}{l|}{ Total } \\
\hline Csángó & 134 & 9 & 31 & 2 & 0 & 176 \\
\cline { 2 - 7 } & $27.8 \%$ & $1.8 \%$ & $6.4 \%$ & $0.4 \%$ & $0 \%$ & $36.5 \%$ \\
\hline \multirow{2}{*}{$\begin{array}{l}\text { Not } \\
\text { Csángó }\end{array}$} & 54 & 71 & 156 & 11 & 14 & 305 \\
\cline { 2 - 7 } & $11.2 \%$ & $14.7 \%$ & $32.4 \%$ & $2.3 \%$ & $2.9 \%$ & $63.3 \%$ \\
\hline \multirow{2}{*}{ Total } & 188 & 80 & 186 & 13 & 14 & 482 \\
\cline { 2 - 7 } & $39 \%$ & $16.6 \%$ & 38.6 & $2.7 \%$ & $2.9 \%$ & $100 \%$ \\
\hline
\end{tabular}

While several elites defined by the snowball sampling have been identified as central in the collaboration network as well, yet other actors - representatives of organizations working on some aspects of the preservation of the Csángó culture, teachers employed in the extracurricular Hungarian classes, etc. - also have key roles by connecting the community with supporters and donors and often bring their own personal network in as well. The teachers play an important role as they liaise between community and donors.

Beyond the actors named in the collaboration network, the Csángó matter involves 
Hanna Edit Kónya, Mixed methodology for the identification of a first generation, transnational, minority elite, perifèria 22(2), diciembre 2017

revistes.uab.cat/periferia

even more supporters, sympathisers and occasional collaborators. Being highly active and known and recognized as someone who is very active, in the presentation and representation of the Csángó matter is however restricted to only couple of individuals. From the total of 482 actors according to In-Degree, betweenness and Egonet Broker, the number of central figures is less than 30.

Being in a leading position in administration at the Csángó Hungarian Association form Moldova, ensures high centrality, however being active in Moldova only, does not seem enough for one to be central in the collaboration network. In order to have a key role in the Csángó matter, one has to participate in events and organizational work both in Moldova and in Hungary as well. For those living in Hungary involvement in events organized in Moldova is even more important. Activity cannot be restrained to only one event or one organization either. Bringing in new social capital for the cause, under the form of new alters ensures central position to the ego. The importance of being active both in Moldova and in Hungary leads to a highly beneficial network position for those who are connecting the two regions and the regional networks, for the opinion leaders and brokers.

\section{The Csángó elites according to teh community - Results of the survey method}

Both the interview and the central roles in the collaboration network identify elites along the presentation and representation of the community and community interests. The question of the status of the elite was highly debated by the interviewees, it is the survey method that is able to show the value system of the community and the feedback towards the definition given by the other research methods.

The short representative survey of 17 questions was asked in one locality, with 182 respondents. Respondents - similarly to the interview subjects - were asked to give their definition of the Csángó elite, to name those they consider member of the elite and to name those who have high prestige and status. Five members of the elite named by the snowball method, are from this village, four of them were named as respected, people with high prestige by the community as well, and one, 
Hanna Edit Kónya, Mixed methodology for the identification of a first generation, transnational, minority elite, perifèria 22(2), diciembre 2017

revistes.uab.cat/periferia

who still lives in the village received high nominations (51 out of 182). Prestige and respect are two major indicators for the village in who they consider successful. Based on these two indicators, nearly 240 people were named, half of whom received only one nomination, and only 14 received 10 or more.

The local priest has the highest prestige and status in the village, he received the highest (60) nominations followed by someone who was one of the firsts to enroll in foreign guest working (with 59 votes) and currently along with his son, a local entrepreneur (51 nominations) they organize work possibilities in Israel for several Csángós, mostly from their own village. Both father and son are highly respected in the village and known as having not only material but high social capital as well. High prestige (42) characterizes teachers in general, but only one elementary teacher received individual (37) nominations. A local entrepreneur, working in agriculture and livestock is another person with several nominations (35), and several survey subjects emphasized that he became locally successful without enrolling in foreign guest working. Having a secure job, - even if otherwise low prestige jobs such as being the local mailman (34), a carpenter (19), a local bar and store owner (13), local forester, the cantor (11) - also ensures respect and recognition of the community. A father enrolled in foreign construction as a guest worker, with work experience in Hungary, Israel and Equatorial Guinea, received 18 nominations for the reason of having all three children in high-school in Transylvania. A church employee also earned the respect of the community (15) for having a priest son. Previous formal high positions in the community - former vicemayor (13), former school principal (10) - also lead to relatively high nominations.

For the community respect highly correlates with having either a well-paying job abroad or having locally a secure, long-term job even if it pays less. People with small or bigger businesses, are highly respected in the village. Several nominees have certain level of migration and foreign guest working experience, and this experience is seen as an important step in self-realization, and this is recognised as one of the most probable ways of success in the community.

Defining who is part of the elite met much stricter filters with this methodology, resulting a much shorter list. From the 240 people who have high prestige and 
Hanna Edit Kónya, Mixed methodology for the identification of a first generation, transnational, minority elite, perifèria 22(2), diciembre 2017

revistes.uab.cat/periferia

status only nine people are considered elites as well, and there is a large distribution in the number of nominations. The highest nominations similarly to prestige and status was received by a local entrepreneur (23) and his father (12), who after the regime change was among the firsts to enroll in foreign guest working and later organized work contracts between Moldova and Israel and the local priest (15), others had 5 or less nominations.

\section{Discussion}

At the beginning of this investigation I expected an elite group mostly formed by current or former migrants, who are key figures in the migration channels in the transmission of labor force from Moldova to other countries and the transmission of information. I assumed that migrants who left the village with the purpose of education and settled in other regions and countries are likely to be seen as elites yet their odds are lower, simply for not being present in the everyday life of the community. Accordingly I expected that the foreign guest-workers act as role models for the young generation seeking a material improvement, while those with studies (abroad) will serve as examples for those who seek to study. Accordingly a material and a cultural elite should be identified if my hypothesis were to be true.

While fieldwork confirmed some of the original assumptions it also defied others and offered a more layered image. The preconception often met regarding the Csángó society, that it doesn't have its cohesive, urban citizenry, intellectual, artisan strata (more details in Pozsony, 2003), the "total lack of stratification by wealth" (Halász, 2002:142) does not stand anymore, yet the Csángó elite is much more divided than initially assumed.

The literature focusing on Csángós always paid special attention to priests and their role in the community, who are often called janissaries, for the role they played in the assimilation of Csángós. The Csángó self-identification of local priests is either very weak, non-existent or strongly rejected, they mostly identify themselves as Catholic and Romanian. While the interviewees see the Romanian ethnic identity of priests as an excluding characteristic from being considered as Csángó elites, the 
Hanna Edit Kónya, Mixed methodology for the identification of a first generation, transnational, minority elite, perifèria 22(2), diciembre 2017

revistes.uab.cat/periferia

community sees priests as the person with the highest prestige and status in the community, whose opinion should be kept, respected and feared. While the ethnic identity of the clerical elite could be seen as an exclusive characteristic if we consider the Hungarian ethnicity/origin of Csángós, it is the most certain group of intellectuals/elites in the Csángó villages. It is also the best-defined group, with most members and with several generations; leaving the validity of their identification as elite an open question.

The findings of the different research methods lead to somewhat different definitions and elite identification not only in the case of priests where ethnic selfidentification is the decision line between those who see them as elite and those who don't, but also in the importance and value of cultural representation. Representatives of the Csángó culture - artists, writers, singers, musicians, etc. known by many people in Hungary are not necessarily recognized in their elite position in Moldova, even less if they are living in Hungary. Several interviewees sustain that for the community is more beneficial a locally present, educated (eg. teacher) person and his/her career in the community, than a much brighter career in Budapest or anywhere else in the world for that matter. Both interviewees and survey subjects agree that all Csángós, regardless of residence, have the duty to do everything for their community, yet the recognition of those who nationally and/or internationally are active in representing the community has a different value in the eyes of the elite and the community. Interviewees agree that in order to be seen as elite by the community, one has to be locally present or to be in regular contact with the local community, and the survey methods proves their assumption as the method identifies nearly exclusively locally present elites, and international cultural representation has a smaller weight in their definition.

The elite belongingness of wealthy Csángós and the existence of an economic elite is strongly questioned by interviewees, arguing that similarly to priests they identify themselves as Romanians, and are not interested nor active in the Csángó matter. These two factors are the cornerstone of the elite definition given by the elite itself, leading to a more homogeneous group description than in the case of the community or the collaboration network. 
Hanna Edit Kónya, Mixed methodology for the identification of a first generation, transnational, minority elite, perifèria 22(2), diciembre 2017

revistes.uab.cat/periferia

Confronting on a closer look the elite nominations of the community, the snowball method (referring to the same community) and the collaboration network, there was only one person out of the four possibilities, identified by all three methods. Elite nominations in the survey method were based on personal successes, and the role played in the Csángó matter as it is seen by the interviewees played little importance. The local entrepreneur and his father were named as elite during the snowball sampling yet they received few nominations and were named nearly exclusively by other Csángós from their village, suggesting that the value of personal success doesn't reach outside of the local community. Locally, stepping out financially form the mass - especially that Moldova is still known as a poverty stricken area - is of high value, yet the interview subjects question the fairness of the wealth of these possible economic elites and they argue that they are not part of the national economic elite, but only successful and wealthy on local level. The identification of the political elite is even harder as the Csángó/Csángó-Hungarian self-identification and a political career seem to be mutually exclusive. The survey method identified the former vice mayor, but for the survey respondent identity played no important role. The collaboration network on the other hand only acknowledges cooperation with local authorities, yet no official plays any central role, while the interviewees couldn't name anyone who they would consider as member of the Csángó political elite.

The different characteristics used by the community and the elite himself results in a double elite definition, with different standards and a parted elite and elite definition. Some members of the younger generation - living in Hungary or in Moldova - could be role models, yet they have higher status in the eyes of scientists, activists, supporters, etc. from Transylvania and Hungary rather than in the eyes of the community.

According to the definition of the elite, one of the most basic expectations towards the elite is to be highly interested and responsible towards the community, be highly educated and not to lose spiritual consciousness, to know, admit and undertake their Csángó or Csángó-Hungarian identity. Meanwhile the expectation of the community towards the elite is to be highly educated and in a good material 
Hanna Edit Kónya, Mixed methodology for the identification of a first generation, transnational, minority elite, perifèria 22(2), diciembre 2017

revistes.uab.cat/periferia

situation.

The division of characteristics that are important for someone to be part of the elite is shown in the next figure.

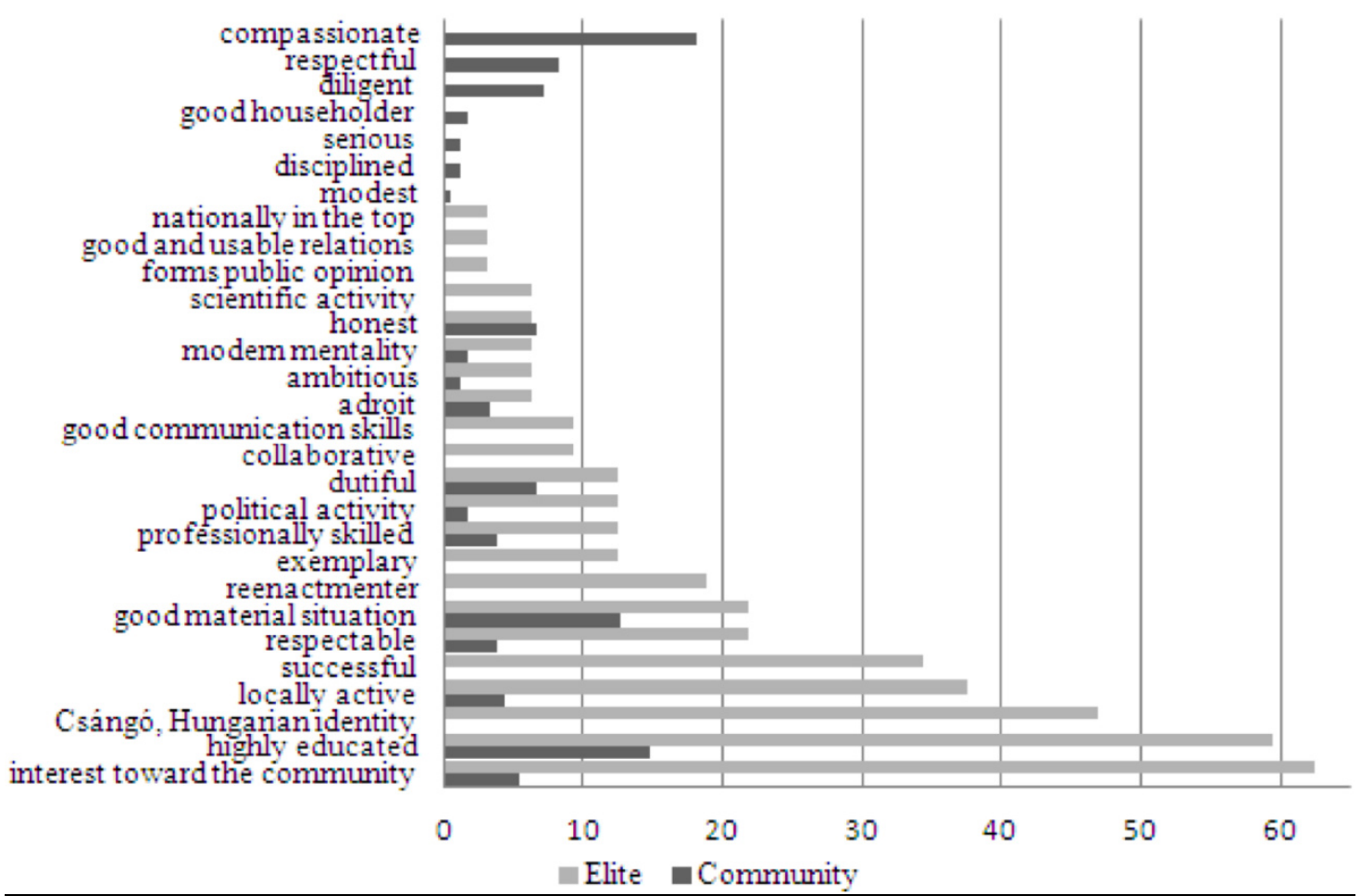

Figure 2: Elite characteristics expected by the community and the elite

itself

Some characteristics are important for both the elites and the community, education for example is in the top of both lists, but plays a much more important role for elites. Being respectful and compassionate are some of those characteristics that were named by the community only, while being present in the national elite or having a good social network and social capital was named only by elites.

The Csángó elite - defined by the interview subjects - seeks to fulfil a leading position of the community in what they consider a path beneficial for the community, and this is shown by their most important requisite for elites: interest toward the community. Interviewees speak about the need of having a group of 
Hanna Edit Kónya, Mixed methodology for the identification of a first generation, transnational, minority elite, perifèria 22(2), diciembre 2017

revistes.uab.cat/periferia

people who is able to think, research and write independently, the demanded requirements being specific to the intellectual category rather the elite. Interviewees and the activity in the collaboration network of the Csángó matter use an elite definition that is based on fulfilled roles and expectations characterizing the responsible intellectual, a category applicable 100 years ago, at the end of 19th beginning of 20th century, when the intellectual was someone who had the role and the goal of leading the community he/she is representing. The community on the other hand defines elites along accumulated capital, firstly material capital rather than roles, goals or representation. For the village is the materially well situated, successful members of the community with high prestige who are the elites.

The elite identified as central actors, opinion leaders and opinion brokers in the collaboration network, have three main characteristics. First, central figures are active in several organizations and events. Those individuals, who are initiating an event or starting an organization, are likely to be central in the greater cooperation network too. Second, there is a ranking among institutions, and it matters to be active in the most important social structures not just any organization or event. Finally, even the elite - identified as both the interviewees and the collaboration network as well, - recognize only a few members as truly active. The elites defined by the snowball sampling play an important role not only in the collaboration network as such, but elites often link together regions, regardless if they live in Moldova (S3) or in Hungary (S2). Several elites identified by the snowball sample are fulfilling the roles of opinion leaders and opinion brokers in the collaboration network, but they are not the only ones who do so. Formal and informal leaders of major organizations also have social capital efficiently used in the Csángó matter. Some of these leaders are not mentioned by other methods as elites and some of them are not even Csángó. The social network analysis of the collaborations within the Csángó matter, show that the representation of the community can be done from as far as $1000 \mathrm{~km}$, yet this representation brings elite status only according to the snowball/interview methodology while the survey gives no clear status validation. According to the interviewees and the social network analysis participant organizations and foundations are in competition not only for funds and donors but 
Hanna Edit Kónya, Mixed methodology for the identification of a first generation, transnational, minority elite, perifèria 22(2), diciembre 2017

revistes.uab.cat/periferia

there is a ranking in what concerns bringing status and recognition as well. The survey on the other hand only sees the visibility of the largest organization. Consequently, interviewees underline that due to a deep sense of duty and remorse for leaving their community, activity in the Csángó matter is more important for Csángós settled in Hungary, yet for those still in Moldova is easier to participate.

\section{Conclusions}

The elite defined by interviewees and the collaboration network, urges the importance of serving and representing the best interests of the community even above personal goals and interests, in the meantime the community awards the personal successes even if no sense of duty towards the community is connected to it. The changes occurring in the social structure of the Csángó community are obvious, even if it is difficult to provide a solid definition. We believe that in the case of an elite identification and definition that is strongly influenced by national and political identities a mixed methodology allows an in-depth view on the heterogeneous aspect of the topic.

\section{Bibliografía}

Arens, M., \& Bein, D. (2004). Katolikus magyarok Moldvában. In Rendhagyó nézetek a csángókról. (pp. 11-91) Budapest: ELTE Román Filológiai Tanszék - A Központi Statisztika Hivatal Levéltára

Benda K. (1989). A moldvai magyarok (csángók) a XVI. XVII. században. In Moldvai csángó-magyar okmánytár 1467 - 1706. (pp. 9-51). Budapest: Magyarságkutató Intézet.

Benkő L. (1989). A csángók eredete és települése a nyelvtudomány szemszögéből. Magyar Nyelv, 85, 271-287, 385-405.

Cohen, A. (1981). The politics of elite culture: explorations in the dramaturgy of power in a modern African society. Berkley, CA: University of California Press. https://doi.org/10.2307/3032052 
Hanna Edit Kónya, Mixed methodology for the identification of a first generation, transnational, minority elite, perifèria 22(2), diciembre 2017

revistes.uab.cat/periferia

Dahl, R. A. (1961). Who Governs? Democracy and Power in an American City. New Haven, Connecticut: Yale University Press.

Domokos P. P. (1987). A moldvai magyarság. Ötödik átdolgozott kiadás. Budapest: Magveto Kiadó.

Etzioni-Halévy, E. (1997). Classes and Elites in Democracy and Democratization. New York: Garland.

Fumanti, M. (2004). The making of the fieldwork-er: debating agency in elites research. Anthropology Matters, 6(2).

Gunda B. (1988). A moldvai magyarok eredete. Magyar nyelv 84, 12-24.

Halász P. (2002). Bokrétába kötögetem vala. A moldvai magyarok néprajzához. Budapest: Európai Folklór Intézet.

Harvey, P. (2002). Elites on the margins: Mestizo traders in the southern Peruvian Andes. In Elite Cultures. Anthropological perspectives. (pp.74-90) London: ASA Monographs v.38.

Higley, J., \& Gunther, R. (1991). Elites and Democratic Consolidation in Latin America and Southern Europe. Cambridge: Cambridge University Press. https://doi.org/10.1017/cbo9781139173902.013

Higley, J., Burton, M. G., \& Field, G.L. (1990). In Defense of Elite Theory: A reply to Cammack, American Sociological Review, 55 (3), 421-426.

https://doi.org/10.2307/2095766

Iorga, N. (1993). Istoria românilor. III., Bucureşti.

Kadushin, C. (1968). Power, Influence and Social Circles: A new methodology for studying opinion makers. American Sociological Review, 33 (5), 685-699.

https://doi.org/10.2307/2092880

King, L. P., \& Szelényi, I. (2004). Theories of the New Class: Intellectuals and Power. Minneapolis - London: University of Minnesota Press. 
Hanna Edit Kónya, Mixed methodology for the identification of a first generation, transnational, minority elite, perifèria 22(2), diciembre 2017

revistes.uab.cat/periferia

Konrád, G., \& Szelényi I. (1979). The Intellectuals on the Road to Class Power. New York: Harcourt, Brace, Jovanovich.

Lasswell, H. D. (1936). Politics: Who Gets What, When How. New York: McGrawHill.

Lee, R. M. (1993). Doing research in sensitive topics. London-Newbury Par-New Delhi: Sage Publications.

Lotter, S. (2004). Studying-up those who fell down: elite transformation in Nepal. Anthropology Matters, 6(2).

Lükơ G. (1936). Moldva alapításának mondáihoz. Ethnographia. XLVII.(1-2), 4856.

Marcus, G. (1983). Elites: Ethnographic Issues. Albuquerque, NM: University of New Mexico Press.

Mărtinaş, D. (1985). Originea ceangåilor din Moldova. Bucureşti: Editura Ştiinţifică şi enciclopedică.

Marx, K. (1846) 2004. The German Ideology. Part one with selections from part two and three and supplementary texts. New York: International Publishers Co.

Munkácsi B. (1902). A moldvai csángók eredete. Ethnographia, XIII (10) 433-440.

Nugent, S. (2002). Gente boa. Elites in and of Amazonia. in Elite Cultures. Anthropological perspectives (pp.61-73). London: ASA Monographs v.38, Routledge.

Pakulski, J., \& Waters, M. (1996). The Reshaping and Dissolution of Social Class in Advanced Society, Theory and Society, 25 (5), 667-691.

https://doi.org/10.1007/bf00188101

Pozsony F. (2002). Ceangåii din Moldova. Cluj: Asociaţia Etnografică Kriza János.

Pozsony F. (2003). A moldvai Csángó-Magyar falvak társadalomszerkezete. Pro Minoritate, pp. 142-165.

Rose, A. M. (1967). The Power Structure. New York: Oxford Universtity Press. 
Hanna Edit Kónya, Mixed methodology for the identification of a first generation, transnational, minority elite, perifèria 22(2), diciembre 2017

revistes.uab.cat/periferia

Rosetti, R. (1905). Despre ungurii şi epicopiile catolice din Moldova. Analele Academiei Române. Seria II. Tom. XXVII (10), 247-322.

Rubinyi M. (1901). A moldvai csángók múltja és jelene. Ethnographia XII (3-4), 115-124, 166-175.

Rustow, D. A., (1966). The Study of Elites: Who's Who, When, and How. World Politics, 18 (4), 690-717.

https://doi.org/10.2307/2009811

Sandu, D. (2005). Emerging Transnational Migration from Romanian Villages. Current Sociology, 53(4)555-582.

Shore, C. \& Nugent, S. (2002). Elite cultures: anthropological perspectives. London: ASA Monographs v.38, Routledge.

https://doi.org/10.4324/9780203426197

Tánczos V. (1997). Hányan vannak a moldvai csángók? Magyar Kisebbség, III (12), 370- 390 . 